\title{
Effective Ways to Improve the Service Ability of Teaching Management in Universities
}

\author{
Yafei Li a , Hongchang Wang ${ }^{b}$ \\ Jilin Agricultural University, Changchun 130118, China \\ a1378795091@qq.com, b731996930@qq.com
}

\begin{abstract}
Teaching management in universities is of great importance and it is the basic guarantee to maintain the normal order of teaching, achieve the training objectives, and improve teaching quality. This paper studies the current status and problems of college management team. On the basis of teaching management and its basic connotation, the current construction of local teaching management team in universities is analyzed. According to the results, effective ways to improve the level of professionalism are proposed in this paper. In terms of cognitive level of professionalism, competition mechanism and overall qualities, the research is expanded.
\end{abstract}

Keywords: Universities; teaching management; professionalism.

\section{Introduction}

Teaching management in the universities is of great importance. Management keeps the efficiency and quality of teaching and it has become a consensus in most universities. High quality and level of management requires a management team of reasonable structure, stable, high quality and strong sense of service specialization. However, working as a key point in teaching process, the teaching management used no to be attached. Currently, the teaching management team in some universities have many problems, for example the service consciousness and working efficiency are low and the team often lacks of education theory which may result in case in teaching process. All in all, a teaching management team with high quality and professional knowledge can improve management efficiency and provide an important condition for teaching quality.

\section{Definition of Professionalism}

Basic functions of universities are to train personnel and teaching work is the center of regular work. Management of teaching in institutions of higher learning plays a particularly important role. Teaching management mainly contains teaching schedule management, teaching operation management, management of teaching quality and evaluation and the basic construction of teaching management. The basic mission of teaching management is to study the law of teaching, to improve the work of management, to improve the quality of teaching and build a teaching order to ensure the normal operation of education. Also, the teaching management team needs to do some research on education revolution and mobilize the enthusiasm of teachers and students in teaching and learning. It can be seen that teaching management is a system engineering of high profession and practice whose functions require not only special management methods and procedures, but need to be familiar with the teaching rules and master the specialized knowledge. Concrete expression of the teaching management staff should behave as:

(1) There should be a set of corresponding theoretical knowledge and technical skills in specific occupations and the managers must receive the necessary education and training;

(2) The managers must bear the important social responsibility, professionalism, service, and professional ethics.

(3) The managers should be different from other industry's relative independence and autonomy, has a certain professional competence. 


\section{Main Problems in Construction of Teaching Management in Universities}

\subsection{Lags in Teaching Management}

All acts of management are based on specific management guidance and concepts. Due to the short running time, low education level, as well as objective factors such as geographical location, economic and cultural development, it leads to errors in the school development in some universities. These universities often emphasize on the construction of teaching staff, while ignoring the improvement of the quality and level of teaching management. It mainly perform as follows:

(1) Firstly, the service concept has not really set up. The essence of teaching management is service which is for teaching and learning.

(2) Secondly, the management mode often pays more attention on experience and functions than innovation and efficiency. Simply positioning the teaching management as routine work and few management actually carries out research work.

\subsection{Structure of Management Team is Irrational}

The quality level of managers directly affects the levels of teaching management, teaching quality and efficiency. It is said that the structure of management team in some universities is irrational. Table 1 shows a survey result in some universities.

Table 1 Structure of Management Team in Some Universities

\begin{tabular}{|c|c|c|c|}
\hline \multicolumn{2}{|c|}{ Item } & Number of People & Proportion \\
\hline \multirow{3}{*}{ Sex } & Male & 31 & 37.8 \\
\cline { 2 - 4 } & Female & 51 & 62.2 \\
\hline \multirow{3}{*}{ Age } & Below 35 & 58 & 70.7 \\
\cline { 2 - 4 } & $35-50$ & 23 & 28.1 \\
\cline { 2 - 4 } & Above 50 & 1 & 1.2 \\
\hline \multirow{3}{*}{ Technical Title } & Primary & 45 & 54.9 \\
\cline { 2 - 4 } & Intermediate & 31 & 37.8 \\
\cline { 2 - 4 } & Senior & 6 & 7.3 \\
\hline \multirow{3}{*}{ Education Background } & Doctor & 0 & 0 \\
\cline { 2 - 4 } & Master & 19 & 23.2 \\
\cline { 2 - 4 } & Bachelor & 51 & 62.2 \\
\cline { 2 - 4 } & Junior College & 12 & 14.6 \\
\hline \multirow{2}{*}{ Specialty } & Management & 21 & 74.4 \\
\hline \multirow{2}{*}{ Working Experience } & Others & 61 & 73.2 \\
\cline { 2 - 4 } & 1-5 years & 60 & 26.8 \\
\cline { 2 - 4 } & More than 6 years & 22 & \\
\hline
\end{tabular}

According to the research above, the structure of the management team is irrational because the number of people with high education background is small. What's more, teaching management staff graduated from other specialty has a large number which cannot adapted to the teaching objective need of scientific management. Referring to the Table, the number of managers with a broad range of work experience is small which may cause panicky situation.

\subsection{Teaching Management System is Not Perfect}

All in all, construction of teaching management system in universities has lagged behind the development of teaching management practice. Moreover, contents of the system are usually vague and focus most on statements of principle. At the same time, in terms of implementation of the system, it involves the personal quality and other kinds of interests which will lead to "ignoring the law". So the implementation of the system is not optimistic. Methods of teaching management modes, are still relatively backward. These kinds of problems bring obstacles to the development of teaching management team.

\section{Measures to Enhance the Professionalization of Teaching Management in Universities}

\subsection{Raising Awareness of the Professionalism of Teaching Management}

Teaching management in universities is a complex exercise. The idea and method of teaching management directly affect the development of school. But looking at the current teaching 
management in universities, it can be found that the teaching management work is only a simple "arranged" work, with traditional management model. In order to build a high-level university, investment in teachers and infrastructure is very important, however, a high quality and efficiency teaching management team also cannot be absent. So universities must change ideas from the school level and be fully aware that teaching management plays an important role in teaching activities. Putting teaching management team and teachers' team on the equally important position is of great significance to the development of university.

\subsection{Establish a Training Mechanism to Improve the Quality of Personnel Management and Capacity}

Training is the basic way to develop human resources and improve the quality of personnel. According to the current situation of teaching management team, training should be execute on different levels and managers should be trained to enhance their operational capacities. Methods of training can be taken as follows:

(1) Pre-job training system should be established. Through training, new teaching management personnel can understand the basic content of their work, acquire the necessary knowledge and methods and grasp the essence of the work as soon as possible.

(2) Establish education scheme and actively encourage managers to improve in-service level of teaching management personnel qualifications which can improve their working capacity and efficiency.

(3) Hold regular or irregular galleries and workshops which can help teaching management staff learn with well-known peers and experts. For middle and senior managers, education management seminar or international conferences will be provided to them to communicate with other experts. All in all, through flexible training mechanisms, it can help managers to learn modern management theory and experience, exploring the law of teaching management in universities to continuously improve teaching management, science literacy and the ability to solve practical problems.

\subsection{Establishing Competition and Incentive Mechanism}

According to the job nature and specific tasks of the teaching management in universities, the responsibility system of teaching management personnel at all levels will be established and implemented. It can clarify their objectives, so that teaching managers can take the appropriate means and methods to their work. With proper means and methods, the work efficiency can be greatly improved. At the same time, performance appraisal is an important means of strengthening management and also it is an important part of human resource development and management in universities. Teaching management work is difficult to quantify. So comprehensive evaluation can be used to examine personnel from every aspect of working conditions, as a basis for reward and punishment assessment results. The outstanding management personnel who has passed the evaluation can be provided with excellent post and salary, especially those with excellent work performance and a certain teaching management research will be considered for a promotion. Through incentive compensation management system, it can allow managers to secure jobs, and outstanding management talent can be attracted and retained which can keep up the good work and motivation.

\section{Summary}

The teaching management system in some universities still has many problems and needs improving. According to the current situation, some kinds of measures are proposed to cope with the problem in this paper. In short, building a high quality teaching management team with a pioneering and innovative spirit of professionalism, is an urgent request for modern higher education in economic and social development. In addition, it is also a firm guarantee for teaching management, teaching work and teaching quality which may lead to the improvement of university competitiveness. 


\section{References}

[1]. Yaohui Chen, Jinhui You. The Discussion on Specialization Construction of the Teaching Management Teams in Colleges and Universities, Education and Teaching Research, Vol. 23 (2009), pp.52-54.

[2].Ruyan Hong. Research on Specialization and Professionalization of Teaching management and University Competitive Advantage, Zhejiang Social Sciences, Vol. 5 (2005), pp.71-74.

[3]. Yigui Deng. Theoretical Studies of People-Oriented College Teaching Administration, Journal of Southwest Agricultural University (Social Science Edition), Vol. 7 (2009), pp. 215-218.

[4]. Junling Zhang. An Exploration into the Scientific Management of Teaching in Universities, Journal of Yangzhou University (Higher Education Study Edition), Vol. 10 (2006), pp. 26-28.

[5]. Meihong Yao, Discussion on Incentive Mechanism in University Teaching Management and Human Care, Journal of Liaoning Institute of Socialism, Vol. 2 (2006), pp. 54-55.

[6]. Zijiang Li, Sihui Chen. Problems and Countermeasures of the Construction of Teaching Management in Colleges and Universities, Journal of Jiaozuo University, Vol. 4 (2002), pp. 9-13. 